\title{
Studi Hubungan antara Tingkat Pendidikan dan Pendapatan Keluarga terhadap Sikap dalam Pengelolaan Sampah Rumah Tangga (studi kasus di Desa Condongcatur, Depok, Sleman, Yogyakarta)
}

\author{
Hijrah Purnama Putra ${ }^{1)}$, Anggun Reza Taufiq, dan Any Juliani \\ Jurusan Teknik Lingkungan \\ Fakultas Teknik Sipil dan Perencanaan, Universitas Islam Indonesia \\ ${ }^{1)}$ email: hijrah_purnama@yahoo.com
}

\begin{abstract}
Abstrak
Laju produksi sampah terus meningkat tidak hanya sebanding dengan laju pertumbuhan penduduk namun juga meningkat seiring dengan perubahan pada pola konsumsi masyarakat. Paradigma lama tentang pengelolaan sampah yang dilakukan masyarakat adalah tentang bagaimana membuang dan memusnahkannya. Sampah yang tidak dikelola dengan baik akan berpengaruh terhadap lingkungan dan kesehatan masyarakat. Peran serta masyarakat secara aktif dalam mengelola sampah sangat menentukan keberhasilan pelaksanaannya. Faktor keadaan masyarakat dalam segi tingkat pendidikan dan pendapatan sangat berpengaruh terhadap keikutsertaan seseorang dalam mengelola sampah. Penelitian ini bertujuan untuk mengetahui apakah terdapat hubungan antara tingkat pendidikan dan pendapatan terhadap sikap dalam pengelolaan sampah rumah tangga. Adapun responden pada penelitian ini adalah 120 keluarga di Desa Condongcatur, Kecamatan Depok yang dipilih secara acak. Metode analisis yang digunakan untuk menguji hipotesis di dalam penelitian ini adalah Multiple Regression Analysis. Hasil penelitian ini menyimpulkan bahwa tingkat pendidikan dan pendapatan berpengaruh secara positif terhadap sikap keluarga dalam pengelolaan sampah rumah tangga di Desa Condongcatur yang ditunjukkan dari data statistik p-value 0.000 untuk tingkat pendidikan, 0.022 untuk pendapatan dengan tingkat signifikan 5\%.
\end{abstract}

Kata kunci : Tingkat Pendidikan, Tingkat Pendapatan, Pengelolaan Sampah Rumah Tangga

\section{PENDAHULUAN}

Lingkungan merupakan bagian dari kehidupan manusia yang saling bergantung satu sama lain. Kebutuhan hidup manusia selalu meningkat seiring dengan meningkatnya kebutuhan masyarakat dan budayanya. Manusia memanfaatkan lingkungan dan alam untuk memenuhi kebutuhannya, bersamaan dengan meningkatnya pembangunan dan usaha manusia. Laju produksi sampah terus meningkat tidak hanya sebanding dengan laju pertumbuhan penduduk namun juga meningkat seiring dengan perubahan pada pola konsumsi masyarakat. Paradigma lama tentang pengelolaan sampah yang dilakukan masyarakat adalah tentang bagaimana membuang dan memusnahkannya. Cara ini tentunya akan membutuhkan lahan yang cukup luas untuk menampung semua sampah yang dihasilkan atau dengan kata lain pengelolaan dilakukan di akhir, tanpa usaha untuk meminimalisasi di sumber. Tanpa disadari bahwa dikemudian hari akan timbul masalah baru, salah satunya penyediaan lahan sampah tempat membuang sampah semakin berkurang dan sempit. Sampah yang tidak dikelola dengan baik akan berpengaruh terhadap lingkungan dan kesehatan masyarakat sekitar. 


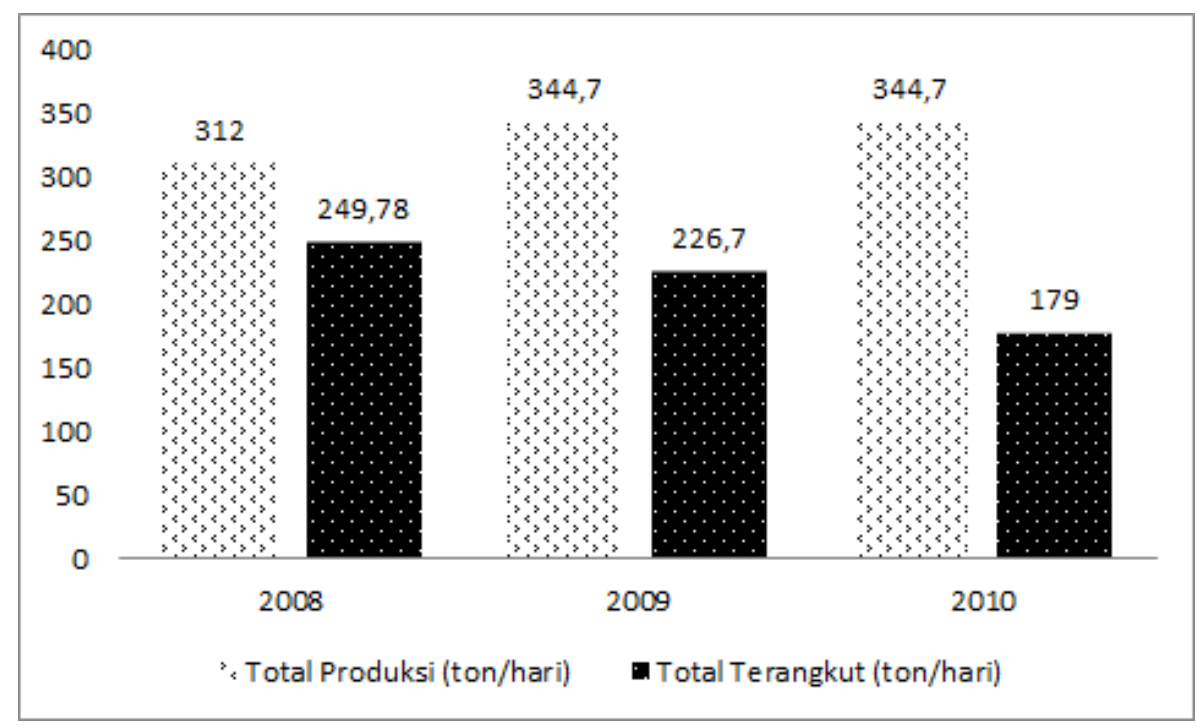

Gambar 1. Perbandingan Produksi Sampah dan Sampah Terangkut ke TPA Piyungan, Yogyakarta (Sumber : Anonim, 2013)

Gambar 1 menunjukkan bahwa sampah yang dihasilkan meningkat setiap tahunnya, namun tidak diimbangi dengan pengelolaan yang baik. Dikarenakan pengelolaan yang dilakukan di akhir suatu sistem, sehingga membutuhkan pembiayaan yang cukup besar untuk melengkapi berbagai fasilitas persampahan. Berikut adalah analisis pembiayaan yang dilakukan terhadap sistem persampahan di Propinsi DIY.

Tabel 1. Pembiayaan Pengelolaan Persampahan di wilayah Aglomerasi Perkotaan Yogyakarta

\begin{tabular}{|l|r|r|r|}
\hline \multicolumn{1}{|c|}{ Uraian } & \multicolumn{1}{|c|}{$\begin{array}{c}\text { Kota } \\
\text { Yogyakarta }\end{array}$} & Sleman & Bantul \\
\hline $\begin{array}{l}\text { Jumlah sampah terlayani } \\
\text { (ton/thn) }\end{array}$ & 122.732 & 20.668 & 10,265 \\
\hline $\begin{array}{l}\text { Biaya pengumpulan dan } \\
\text { pengangkutan (juta rupiah) }\end{array}$ & $2.051,3$ & 776,3 & 256,0 \\
\hline $\begin{array}{l}\text { Sharing Biaya O \& M TPA } \\
\text { (juta rupiah) }\end{array}$ & $1.635,6$ & 174,4 & 86,6 \\
\hline $\begin{array}{l}\text { Total biaya sampah } \\
\text { (juta rupiah) }\end{array}$ & $3.086,9$ & 950,7 & 351,6 \\
\hline $\begin{array}{l}\text { Penerimaan retribusi } \\
\text { (juta rupiah) }\end{array}$ & 700,5 & 393,5 & 130,4 \\
\hline $\begin{array}{l}\text { Persentase penerimaan terhadap } \\
\text { pengeluaran }\end{array}$ & $\mathbf{2 3 \%}$ & $\mathbf{4 0} \%$ & $\mathbf{3 7} \%$ \\
\hline
\end{tabular}

Sumber : Sugiarto, 2006 
Sampah adalah sisa kegiatan sehari-hari manusia dan atau dari proses alam yang berbentuk padat (Suyoto, 2008). Peran serta masyarakat secara aktif dalam mengelola sampah sangat menentukan keberhasilan pelaksanaannya. Faktor keadaan masyarakat dalam segi tingkat pendidikan dan pendapatan sangat berpengaruh terhadap keikutsertaan seseorang dalam mengelola sampah. Tingkat pendidikan seseorang mempengaruhi tingkat partisipasinya dalam sebuah kegiatan (Pangestu, 1995). Semakin tinggi pendidikan seseorang maka semakin mudah memberi informasi dan pembinaan. Tingkat pendapatan keluarga dapat memberikan pengaruh yang besar terhadap kegiatan penanganan sampah. Orang yang memiliki pendapatan tinggi cenderung melakukan penanganan lebih baik, misalnya, mereka akan menyediakan tempat sampah di dalam maupun di luar rumah serta membayar orang lain untuk menangani sampah yang mereka hasilkan.

Penelitian ini bertujuan untuk mengetahui hubungan antara tingkat pendidikan dan pendapatan keluarga dengan sikap dalam pengelolaan sampah rumah tangga di wilayah Kelurahan Condongcatur, Kecamatan Depok. Jumlah penduduk di Desa Condongcatur yaitu 36.740 jiwa dengan sex Ratio 102,58 yang berarti bahwa dalam setiap 100 jiwa penduduk perempuan terdapat sejumlah 103 jiwa penduduk laki-laki. Tingkat kepadatan penduduk Desa Condongcatur dihitung dengan membagi antara jumlah penduduk dan luas wilayah dalam satuan kilometer persegi. Luas wilayah Desa Condongcatur adalah $9,50 \mathrm{~km}^{2}$, maka tingkat kepadatan penduduknya adalah 3.867 yang berarti bahwa untuk setiap 1 (satu) $\mathrm{km}^{2}$ dihuni oleh 3.867 jiwa penduduk. Semakin banyak jumlah penduduk dan semakin sempit luas wilayahnya akan menimbulkan angka kepadatan yang tinggi.

Tabel 2. Perbandingan Kepadatan Penduduk Desa Condongcatur dan di Kecamatan Depok Tahun 2012

\begin{tabular}{|c|c|c|c|c|c|c|}
\hline \multirow{2}{*}{$\begin{array}{c}\text { Desa / } \\
\text { Kecamatan }\end{array}$} & \multirow{2}{*}{$\begin{array}{c}\text { Luas } \\
\left(\mathbf{K m}^{2}\right)\end{array}$} & \multicolumn{2}{|c|}{ Jenis Kelamin } & \multirow{2}{*}{ Jumlah } \\
\cline { 3 - 4 } & & $\begin{array}{c}\text { Laki- } \\
\text { laki }\end{array}$ & Perempuan & Penduduk & $\begin{array}{c}\text { Sex } \\
\text { Ratio }\end{array}$ & $\begin{array}{c}\text { Kepadatan } \\
\text { Penduduk }\end{array}$ \\
\hline $\begin{array}{c}\text { Desa } \\
\text { Condongcatur }\end{array}$ & 9,50 & 18.630 & 18.110 & 36.740 & 102,87 & 3.867 \\
\hline $\begin{array}{c}\text { Kecamatan } \\
\text { Depok }\end{array}$ & 35,55 & 64.165 & 60.434 & 124.599 & 106,17 & 3.505 \\
\hline
\end{tabular}

Sumber : Kecamatan Depok dalam Angka, 2012

Pengelolaan sampah rumah tangga meliputi dua kegiatan pokok yaitu kegiatan untuk mengurangi sampah dan kegiatan untuk menangani sampah. Mengurangi sampah bertujuan agar jumlah atau kuantitas sampah dapat ditekan atau diperkecil (reduce), memanfaatkan kembali sampah (reuse), dan pendaurulangan sampah (recycle). Sedangkan penanganan sampah dimaksudkan untuk 
menangani keberadaan sampah yang kian bertambah seiring pertambahan waktu. Tujuannya agar sampah yang timbul di lingkungan rumah tangga tidak mengganggu kesehatan dan kehidupan manusia sehari-hari. Kegiatan penanganan sampah meliputi pemilahan dan pemisahan sampah sesuai dengan jenis sampah, pengumpulan sampah dalam bentuk pengambilan dan pemindahan dari sumber sampah ke tempat penampungan sementara, pengangkutan sampah dalam bentuk membawa sampah dari sumber dan atau tempat penampungan sementara ke tempat pemrosesan terakhir, pengolahan sampah dalam bentuk mengubah karakteristik dan komposisi serta jumlah sampah, pemrosesan akhir sampah dalam bentuk pengembalian sampah dan atau residu hasil pengolahan sampah ke media lingkungan secara aman bagi manusia. Dengan melakukan kegiatan pengurangan dan penanganan sampah diharapkan dapat menangani sampah di mulai dari sumber.

Berikut adalah beberapa penelitian terdahulu yang pernah dilakukan terkait hubungan antara tingkat pendidikan, pendapatan terhadap sikap pengelolaan sampah. Sulestri (2001) telah melakukan penelitian terkait hubungan tingkat pendidikan dan sikap ibu rumah tangga dengan pengelolaan sampah domestik. Dari hasil penelitian terdapat hubungan positif dan signifikan antara tingkat pendidikan dan pengelolaan sampah domestik $r$ hitung $>r$ tabel atau 0,783 >0,153 pada taraf signifikansi 5\%. Suprapto (2010) melakukan penelitian hubungan tingkat pendidikan dan pendapatan terhadap pengelolaan sampah di Grobogan. Hasil penelitian menunjukkan adanya hubungan positif antara tingkat pendidikan dan pendapatan terhadap sikap keluarga dalam pengelolaan sampah karena $\mathrm{r}$ hitung lebih besar daripada $\mathrm{r}$ tabel pada tingkat signifikasi $5 \%$. Demikian pula penelitian yang dilakukan oleh Sutoto (2002) tentang sikap dan partisipasi masyarakat dalam pengelolaan sampah. Hasil dari penelitian adalah ada perbedaan antara sikap masyarakat dalam pengelolaan sampah di Perumahan Songgolangit dan Baturan Kabupaten Grobogan. Tingkat responden antara dua perumahan dengan perbedaan keberhasilan dalam pengelolaan sampah di perumahan Baturan 68,75 dan di perumahan Songgolangit 64,70 . nilai t tabel $=$ 2,032 dan $\mathrm{t}$ hitung 3,243 (pada tingkat signifikansi 5\%). Disamping itu, penelitian yang dilakukan oleh Aprianto (2008) tentang tingkat partisipasi warga dalam pengelolaan lingkungan berbasis masyarakat (kasus Kampung Hijau Rawajati, Kecamatan Pancoran, Kotamadya Jakarta Selatan, Provinsi DKI Jakarta). Hasil dari penelitian bahwa umur, tingkat pendidikan, tingkat pendapatan dan beban keluarga tidak berhubungan nyata atau signifikan dengan tingkat partisipasi warga kampung Rawajati dalam pengelolaan lingkungan. Tingkat partisipasi tinggi adalah 96,67\% responden dengan tingkat pendidikan yang rendah, sedangkan 8,33\% dari responden berpendidikan tinggi memiliki partisipasi rendah dan $13,7 \%$ nya memiliki partisipasi tinggi. 


\section{METODE PENELITIAN}

Penelitian ini dilakukan di Desa Condongcatur yang terletak di Kecamatan Depok Kabupaten Sleman, Propinsi Jawa Tengah. Sampel adalah sebagian dari jumlah dan karakteristik yang dimiliki oleh populasi. Apabila populasi besar dan peneliti tidak mungkin mempelajari semua yang ada pada populasi, maka dapat menggunakan sampel yang diambil dari populasi. Untuk memastikan berapa jumlah sampelnya, penulis menggunakan formula Slovin (Umar, 1997)

$$
n=\frac{N}{1+N e^{2}}
$$

dimana:

$\mathrm{n}=$ Sampel

$\mathrm{e}=$ Percentage of error $10 \%$

$\mathrm{N}=$ Populasi

Dengan menggunakan persamaan di atas, jumlah minimal sampel yang sesuai adalah 99 sampel. Pada penelitian ini, peneliti menggunakan 120 sampel dan telah memenuhi sampel minimal. Teknik sampling yang dilakukan dalam penelitian ini adalah dengan metode sampling acak berlapis atau stratified random sampling. Metode pemilahan sampel dengan cara membagi populasi ke dalam kelompok-kelompok yang homogen yang disebut strata. Dimana proses pengambilan sampel dilakukan dengan acak dari setiap strata yang dipilih. Proses pemilihan sejumlah sampel (n) dari populasi $(\mathrm{N})$ dilakukan secara random.

Sebelum dilakukan penyebaran kuisioner, dilakukan uji validitas dan reliabilitas. Uji validitas dalam penelitian ini digunakan untuk mengukur kevalidan kuesioner yang dipakai. Validitas menggambarkan tingkat ketepatan suatu alat ukur mampu melakukan fungsi. Pengujian tingkat validitas instrumen penelitiaan menggunakan software SPSS dimana apabila $r$ hitung > $r$ tabel, maka kesimpulannya item kuesioner tersebut valid, akan tetapi apabila $r$ hitung $<\mathrm{r}$ tabel, maka kesimpulannya item kuesioner tersebut tidak valid. Uji reliabilitas berfungsi untuk mengetahui bagaimana butir-butir pertanyaan dalam suatu kuesioner saling berhubungan, mendapatkan nilai $\alpha$ yang merupakan indeks Internal Consistency dari skala pengukuran secara keseluruhan, dan mengidentifikasi butir-butir pertanyaan dalam kuesioner yang bermasalah harus direvisi atau dihilangkan. 
Cara yang digunakan untuk menguji reliabilitas kuesioner adalah dengan menggunakan rumus koefisien reliabilitas Cronbach Alpha pada SPSS. Pengujian reliabilitas terhadap seluruh item atau pertanyaan pada penelitian ini akan menggunakan rumus koefisien Cronbach Alpha. Bila memperoleh hasil yang cukup tinggi maka akan diketahui reliabi litas yang sesungguhnya lebih tinggi akan tetapi bila koefisiennya rendah maka belum bisa memastikan apakah tes tersebut memiliki reliabilitas rendah ataukah hal itu sekedar indikasi tidak terpenuhinya asumsi (Allen \& Yen, 1979 dalam Anwar, 1992). Cronbach Alpha kritis pada penelitian ini menggunakan nilai 0,60 dengan asumsi bahwa daftar penilaian yang diuji dikatakan reliabel bila nilai Cronbach alpha > 0,60 .

Metode analisis data yang digunakan adalah analisis regresi berganda yang bertujuan untuk mengetahui variabel independen $\left(\mathrm{X}_{1}, \mathrm{X}_{2}\right)$ terhadap variable dependen $(\mathrm{Y})$. Persamaan variabel yang diperoleh dalam proses perhitungan, harus diuji secara statistik nilai koefisien regresinya. Apabila semua koefisien regresi signifikan, persamaan regresi yang diperoleh dapat dipergunakan untuk memprediksi nilai variabel independen, jika nilai-nilai veriabel independen ditentukan. Seberapa besar pengaruh variabel independen (X) terhadap variabel dependen ( $\mathrm{Y}$ ) dapat diukur dengan besarnya nilai koefisien determinasi $\left(\mathrm{R}^{2}\right)$ yang dapat ditemukan pada hasil perhitungan.

Definisi operasional dari variabel yang digunakan dalam penelitian mengenai sikap keluarga terhadap pengelolaan sampah rumah tangga adalah:

1. Tingkat pendidikan responden adalah Tingkat terakhir sekolah formal yang pernah diikuti responden. Tingkat pendidikan dibagi menjadi dua yaitu rendah dan tinggi. Dikatakan rendah jika pendidikan responden adalah TK/SD/SMP, dan dikatakan tinggi apabila SMA/DIPLOMA/SARJANA.

2. Tingkat pendapatan adalah rata-rata jumlah hasil kerja berupa uang yang diperoleh responden setiap bulan. Tingkat pendapatan responden dibagi menjadi dua yaitu rendah dan tinggi. Dikatakan rendah jika pendapatan responden < Rp. 1.500.000,00 per bulan dan dikatakan tinggi apabila $\geq$ Rp. $1.500 .000,00$ per bulan.

3. Sikap terhadap pengelolaan sampah dibagi menjadi dua yaitu rendah dan tinggi. Penilaian terhadap sikap pengelolaan sampah dilakukan dengan cara menjumlah skor dari tiap pertanyaan dari kuisioner. Sehingga tingkat sikap dapat dikategorikan menjadi tinggi apabila skor $>20$ dan dikatakan rendah apabila skor $\leq 20$. 


\section{HASIL DAN PEMBAHASAN}

Analisa regresi berganda untuk menguji hipotesis, menguji hubungan antara pendidikan dan pendapatan terhadap sikap keluarga dalam mengelola sampah rumah tangga $\left(\mathrm{H}_{1}, \mathrm{H}_{2}\right.$, dan $\left.\mathrm{H}_{3}\right)$.

Tabel 3. Ringkasan Model

\begin{tabular}{|c|r|r|r|r|}
\hline Model & R & R Square & $\begin{array}{c}\text { Adjusted R } \\
\text { Square }\end{array}$ & $\begin{array}{c}\text { Std. Error of } \\
\text { the Estimate }\end{array}$ \\
\hline 1 & 0.902 & 0.813 & 0.810 & 0.23130 \\
\hline
\end{tabular}

Data di atas menunjukkan bahwa adjusted $\mathrm{R}^{2}$ adalah 0.810 mempunyai pengertian bahwa tingkat pendidikan dan pendapatan mempengaruhi sikap keluarga terhadap pengelolaan sampah sebesar $81 \%$ dimana 19\% sisanya dipengaruhi oleh faktor lain yang tidak dijelaskan dalam penelitian ini, seperti misalnya faktor psikologis terhadap sampah, motivasi diri, dan atau faktor dukungan pemerintah setempat, sosialisasi, dll. Untuk menguji pengaruh antara variabel bebas terhadap variabel terikat, digunakan uji T-test. Jika significance value (p-value) lebih kecil dari 0.05, maka $\mathrm{H}_{\mathrm{o}}$ dapat ditolak oleh $\alpha=5 \%$ sehingga variabel bebas secara statistik mempengaruhi variabel terikat.

\section{Hubungan antara tingkat pendidikan dengan sikap keluarga dalam pengelolaan sampah rumah tangga}

Suprapto (2010) dalam penelitiannya menyatakan bahwa tingkat pendidikan keluarga menentukan sikapnya dalam hal mengelola sampah rumah tangga. Hal sama juga dikemukakan oleh Pangestu (1995) menyatakan bahwa tingkat pendidikan seseorang mempengaruhi tingkat partisipasi pada suatu kegiatan. Semakin tinggi pendidikan seseorang maka semakin mudah memberi informasi dan pembinaan. Tetapi sebaliknya, ia juga menyebutkan bahwa semakin tinggi pendidikan seseorang maka tingkat partisipasinya semakin rendah, karena semakin banyak alternatif baginya untuk mencari kegiatan diluar.

Kriteria sikap dibagi menjadi dua yaitu rendah dan tinggi. Dikatakan rendah jika penilaian terhadap sikap pengelolaan sampah dengan menjumlah skor dari tiap pertanyaan dari kuisioner. Sehingga tingkat sikap dapat dikategorikan menjadi tinggi apabila skor $>20$ dan dikatakan rendah apabila skor $\leq 20$. 
Tabel 4. Jumlah Responden menurut Tingkat Pendidikan dan Sikap Keluarga dalam Pengelolaan Sampah Rumah Tangga di Desa Condongcatur

\begin{tabular}{|c|c|c|c|c|c|c|}
\hline \multirow{3}{*}{$\begin{array}{c}\text { Sikap } \\
\text { terhadap } \\
\text { Pengelolaan } \\
\text { Sampah }\end{array}$} & \multicolumn{4}{|c|}{ Tingkat Pendidikan } & \multirow{2}{*}{\multicolumn{2}{|c|}{ Jumlah }} \\
\hline & \multicolumn{2}{|c|}{ Rendah } & \multicolumn{2}{|c|}{ Tinggi } & & \\
\hline & $\mathbf{n}$ & $\%$ & $\mathbf{n}$ & $\%$ & $\mathbf{n}$ & $\%$ \\
\hline Tinggi & 2 & 7.41 & 56 & 60.22 & 58 & 48 \\
\hline Rendah & 25 & 92.59 & 37 & 39.78 & 62 & 52 \\
\hline Jumlah & 27 & 100 & 93 & 100 & 120 & 100 \\
\hline
\end{tabular}

Tabel 4 menunjukkan bahwa responden yang memiliki sikap terhadap pengelolaan sampah rumah tangga yang tinggi sebesar $60.22 \%$ dengan tingkat pendidikan yang tinggi, sedangkan 92.59\% responden berpendidikan rendah memiliki sikap yang rendah pula. Sebanyak $7.41 \%$ responden yang berpendidikan rendah memiliki sikap yang tinggi terhadap pengelolaan sampah, sedangkan $39.78 \%$ responden berpendidikan tinggi sikapnya cenderung rendah.

Responden dengan tingkat pendidikan tinggi lebih tertarik untuk mencoba hal baru terutama dalam segi pemilahan sampah, pendaur ulangan, membuat kreativitas dari sampah plastik menjadi barangbarang berguna seperti tas dan dompet, serta pemanfaatan sampah lainnya yang dapat bermanfaat bagi lingkungan. Sebaliknya responden dengan pendidikan rendah cenderung bersikap negatif dalam pengelolaan sampah, seperti langsung membakar sampah di pinggir jalan/tong sampah pribadi, langsung membuang ke pinggir jalan dan membuang ke sungai/parit di dekat rumah tinggal.

Tabel 5. Hasil uji T-test untuk Tingkat Pendidikan

\begin{tabular}{|c|r|r|r|r|r|}
\hline \multirow{2}{*}{ Model } & \multicolumn{2}{|c|}{$\begin{array}{c}\text { Unstandardized } \\
\text { Coefficients }\end{array}$} & $\begin{array}{c}\text { Standardized } \\
\text { Coefficients }\end{array}$ & \multirow{2}{*}{ t } & \multirow{2}{*}{ Sig. } \\
\cline { 2 - 4 } & \multicolumn{1}{|c|}{ B } & Std. Error & \multicolumn{1}{|c|}{ Beta } & & \\
\hline Tingkat Pendidikan & 0.337 & 0.035 & 0.744 & 9.618 & 0.00 \\
\hline
\end{tabular}

Hasil penelitian dari data statistik menunjukkan p-value untuk tingkat pendidikan adalah 0.000 atau kurang dari $\alpha=0.05$, artinya tingkat pendidikan mempengaruhi sikap keluarga dalam pengelolaan sampah rumah tangga di Desa Condongcatur. Hal ini menunjukkan bahwa ada hubungan positif antara tingkat pendidikan dengan sikap keluarga terhadap pengelolaan sampah rumah tangga di Kelurahan Condongcatur, Kecamatan Depok. Semakin tinggi tingkat pendidikan seseorang, akan semakin tinggi pula sikapnya terhadap pengelolaan sampah rumah tangga. 


\section{Hubungan antara tingkat pendapatan dengan sikap keluarga dalam pengelolaan sampah rumah tangga}

Pangestu (1995) menyatakan bahwa selain tingkat pendidikan, tingkat pendapatan juga merupakan faktor yang mempengaruhi partisipasi atau sikap seseorang terhadap sesuatu. Suprapto (2010) juga mengatakan bahwa tingkat pendapatan keluarga menentukan sikapnya dalam hal mengelola sampah rumah tangga. Demikian juga dengan Sulestri (2001) mengungkapkan hal sama bahwasanya tingkat pendapatan seseorang sangat mempengaruhi sikapnya terhadap pengelolaan sampah. Semakin tinggi pendapatan keluarga, akan semakin tinggi pula sikapnya untuk mengelola sampah rumah tangga, begitu juga sebaliknya.

Tabel 6. Jumlah Responden menurut Pendapatan dan Sikap Keluarga dalam Pengelolaan Sampah Rumah Tangga di Desa Condongcatur

\begin{tabular}{|c|c|c|c|c|c|c|}
\hline \multirow{2}{*}{$\begin{array}{c}\text { Sikap } \\
\text { terhadap } \\
\begin{array}{c}\text { Pengelolaan } \\
\text { Sampah }\end{array}\end{array}$} & \multicolumn{4}{|c|}{ Rendah } & \multicolumn{2}{c|}{ Tumlah } \\
\cline { 2 - 7 } & $\mathbf{n}$ & $\%$ & $\mathbf{n}$ & $\%$ & $\mathbf{n}$ & $\%$ \\
\hline Tinggi & 3 & 9.09 & 56 & 64.37 & 59 & 49 \\
\hline Rendah & 30 & 90.91 & 31 & 35.63 & 61 & 51 \\
\hline Jumlah & 33 & 100 & 87 & 100 & 120 & 100 \\
\hline
\end{tabular}

Tabel 6 menunjukkan bahwa responden dengan pendapatan tinggi memiliki partisipasi sikap terhadap pengelolaan sampah yang tinggi yaitu sebesar $64.37 \%$ responden berpendapatan tinggi dan sebesar $9.09 \%$ responden berpendapatan rendah memiliki sikap yang tinggi terhadap pengelolaan sampah. Sebanyak $35.63 \%$ responden berpendapatan tinggi ada yang memilih sikap yang cenderung rendah dan $90.91 \%$ responden berpendapatan rendah mengindikasikan partisipasi sikap yang rendah pula. Pada variabel ini secara umum menunjukkan bahwa responden yang memiliki pendapatan tinggi menunjukkan partisipasi sikap yang tinggi dalam mengelola sampah rumah tangga. Masyarakat dengan pendapatan rendah cenderung enggan untuk mengelola sampah rumah tangganya, kebanyakan dari mereka langsung membuang begitu saja ke sungai atau langsung membakar sampahnya.

Tabel 7. Hasil uji T-test untuk Tingkat Pendapatan

\begin{tabular}{|l|r|r|r|r|r|}
\hline \multirow{2}{*}{ Model } & \multicolumn{2}{|c|}{$\begin{array}{c}\text { Unstandardized } \\
\text { Coefficients }\end{array}$} & $\begin{array}{l}\text { Standardized } \\
\text { Coefficients }\end{array}$ & \multirow{2}{*}{ t } & \multirow{2}{*}{ Sig. } \\
\cline { 2 - 5 } & \multicolumn{1}{|c|}{ B } & Std. Error & \multicolumn{1}{c|}{ Beta } & & \\
\hline $\begin{array}{l}\text { Tingkat } \\
\text { Pendapatan }\end{array}$ & 0.067 & 0.029 & 0.179 & 2.32 & 0.022 \\
\hline
\end{tabular}


Hasil dari penelitian ini juga memperlihatkan bahwa p-value untuk pendapatan keluarga adalah 0.022 atau kurang dari $\alpha=0.05$, kondisi ini mengartikan bahwa pendapatan keluarga mempengaruhi sikap keluarga dalam pengelolaan sampah rumah tangga di Desa Condongcatur. Berdasarkan penelitian ini, keluarga yang berpendapatan tinggi akan lebih peduli untuk mengelola sampah rumah tangganya dibanding dengan keluarga yang pendapatannya lebih rendah.

\section{Hubungan antara tingkat pendidikan dan pendapatan keluarga dengan sikap keluarga dalam pengelolaan sampah rumah tangga}

Tabel 8. Hasil F-Test

\begin{tabular}{|c|r|r|r|r|r|}
\hline Model & $\begin{array}{c}\text { Sum of } \\
\text { Squares }\end{array}$ & \multicolumn{1}{c|}{ df } & \multicolumn{1}{c|}{$\begin{array}{c}\text { Mean } \\
\text { Square }\end{array}$} & \multicolumn{1}{c|}{ F } & Sig. \\
\hline Regression & 27.268 & 2 & 13.634 & 254.842 & .000 \\
Residual & 6.260 & 117 & .054 & & \\
Total & 33.528 & 119 & & & \\
\hline
\end{tabular}

Peneliti menggunakan $\mathrm{F}$ test untuk mengetahui apakah variabel bebas dapat mempengaruhi variabel terikat secara bersama-sama. Berdasarkan data statistik, nilai $\mathrm{F}$ adalah 254.842 dengan signifikan $\mathrm{F}$ $0.000 \alpha=5 \%$. Sehingga jika F significant value kurang dari 0.05, maka variabel bebas secara statistik bersama-sama mempengaruhi variabel terikat.

Hasil perhitungan menunjukkan significance value (p-value) adalah 0.000 (kurang dari 0.05). Artinya variabel bebas yang terdiri dari tingkat pendidikan dan pendapatan keluarga secara positif bersama-sama mempengaruhi sikap keluarga dalam pengelolaan sampah rumah tangga. Keluarga yang berpendidikan rendah dan memiliki penghasilan relatif rendah di Desa Condongcatur, Kecamatan Depok akan lebih kurang peduli terhadap pengelolaan sampah yang baik dibanding dengan keluarga yang berpendidikan lebih tinggi dan penghasilan tinggi.

\section{KESIMPULAN}

1. Tingkat pendidikan keluarga di Desa Condongcatur berpengaruh positif dengan sikap keluarga terhadap pengelolaan sampah rumah tangga. Semakin tinggi tingkat pendidikan, maka semakin baik pula sikapnya terhadap pengelolaan sampah.

2. Tingkat pendapatan keluarga di Desa Condongcatur berpengaruh positif dengan sikap keluarga terhadap pengelolaan sampah rumah tangga. Semakin tinggi pendapatan keluarga, akan semakin tinggi pula sikapnya untuk mengelola sampah rumah tangga. 
3. Tingkat pendidikan dan tingkat pendapatan secara bersama-sama memberikan hasil positif mempengaruhi sikap keluarga terhadap pengelolaan sampah rumah tangga. Semakin tinggi tingkat pendidikan dan pendapatan keluarga di Desa Condongcatur maka akan semakin tinggi pula sumbangan positif yang diberikan dalam menentukan sikapnya untuk mengelola sampah rumah tangga.

\section{DAFTAR PUSTAKA}

Anonim, 2012, Kecamatan Depok dalam Angka tahun 2012, Badan Pusat Statistik Kabupaten Sleman, Yogyakarta

Anonim, 2013, Memorandum Program Sanitasi Tahun 2013-2018, Pokja Sanitasi Kota Yogyakarta, Bappeda DIY, Yogyakarta

Anwar, S., 1992. Reliabilitas dan Validitas, Edisi Sigma Alpha, Yogyakarta

Aprianto, Y., 2008. Tingkat Partisipasi Warga dalam Pengelolaan Lingkungan Berbasis Masyarakat, Skripsi, Institut Pertanian Bogor, Bogor

Pangestu, M.H.T., 1995. Partisipasi Masyarakat dalam Pelaksanaan Kegiatan Perhutanan Sosial (Studi Kasus: KPH Cianjur, Jawa Barat), Tesis Pascasarjana, Institut Pertanian Bogor, Bogor

Sugiarto, R., 2006, Wajah Persampahan Yogyakarta : Pengelolaan yang Jalan di Tempat, Balairung Jurnal Mahasiswa Universitas Gadjah Mada, Edisi 39, Yogyakarta

Sulestri, I.S., 2001, Hubungan Tingkat Pendidikan dan Sikap Ibu Rumah Tangga dengan Pengelolaan Sampah Domestik, Jurnal Lingkungan, Vol 13 Nomor 5, Hal 102-121

Suprapto, 2010, Pengelolaan Sampah Rumah Tangga di Desa Candisari Kabupaten Grobogan. Jurnal Penelitian, Vol 13 Nomor 1, Hal 45-79

Sutoto, 2002, Sikap dan Partisipasi Masyarakat dalam Pengelolaan Sampah, Jurnal Penelitian, Vol 5. Nomor 02, Hal 83-124

Suyoto, B., 2008, Rumah Tangga Peduli Lingkungan, Prima Media, Jakarta

Umar, H., 1997, Metodologi Penelitian: Aplikasi dalam Pemasaran, Gramedia, Jakarta 